\title{
Gaceta Médica de México is the memory of Mexico's medicine and physicians
}

Francisco Espinosa-Larrañaga*

Gaceta Médica de México, Mexico City, Mexico

.there was a famous Egyptian old god, whose name was Theuth, (...) and he was the inventor of many arts, such as arithmetic and calculation and geometry and astronomy and draughts and dice, but his great discovery was the use of letters. (...) to the king of Thebes and of the whole country of Egypt came Theuth and showed his inventions, desiring that the other Egyptians might be allowed to have the benefit of them; (...) the king enquired about their several uses, (...). But when they came to letters, "This," said Theuth, "will make the Egyptians wiser and give them better memories; it is a specific both for the memory and for the wit".

The king replied: "O most ingenious Theuth! (...) this discovery of yours will create forgetfulness in the learners' souls, because they will not use their memories, they will trust to the external written characters and not remember of themselves.

Phaedrus. Plato

Passage (247c-275b)

Having developed an articulate language was a great breakthrough for mankind. The creation of a writing system and its reading enabled the development of collective memory, social awareness, interpretation of emotions and, ultimately, creativity as an evidence of intellectual maturity.

Writing gave rise to documents and subsequently to books, whose origin is considered to date back to more than 5,000 years, as well as to the subject who wrote and to the subject it was written for. ${ }^{2,3}$

Since ancient times, the value of a book appeared to be within the object itself, since first it was commercialized and manually reproduced or by handcrafted until the discovery of the printing press. The protection of books in libraries or religious spaces such as monasteries is a sign of the value society conferred to writing, to documents, to scribes, to information and to book owners or to those who had the ability to read and write. ${ }^{4,5}$
Through books and writing, the transmission of knowledge, worldview and interpretation of cultures was carried out, but at the same time, sciences such as mathematics, geometry, astronomy and even the art of healing were also diffused. Since ancient times, the book has been considered a depositary of knowledge and an educational instrument. ${ }^{3,6}$ The establishment and systematization of a method to create knowledge, something that currently is known as scientific method, increased the velocity of discovery.

The popularity and development of types and linotype, in addition to the founding of several printing houses in different countries, allowed printing documents more easily and gave rise to the development of a different type of publication other than books, based on the concept of newspaper. ${ }^{5}$

In the first half of the $18^{\text {th }}$ century, the diffusion of scientific knowledge used a new format for the first time: the medical journal, with the foundation of Medical Assays and Observations in 1733, which eventually would become the Scottish Medical Journal. In turn, since its inception in 1812, the New England Journal of Medicine aimed at exchanging experiences between professionals, in a propitious environment for research and reflection. In 1823, The Lancet made its appearance, in 1843, The Journal of the American Medical Association (JAMA), and in 1857, The British Medical Journal. In Mexico, seven years later, in 1864, Gaceta Médica de México appeared, before the dean of French magazines, La Presse Médicale, which saw the light almost 30 years later, in 1893. ${ }^{6}$

Currently, with the Internet and with the development of information and communication technologies (ICT), we are experiencing a change of model in medical journals: in some cases, printed and
Gac Med Mex. 2019;155:308-310

Contents available at PubMed www.gacetamedicademexico.com 
electronic formats coexist; in others, publications have fully migrated to this new platform, and some are even "born" being electronic in nature. Notwithstanding, writing a scientific document, and writing itself, persist as an archetype of human graphic communication.

Applied to the diffusion of knowledge, ICTs have enabled the development of systems that allow editing and publishing times to be shortened. They have also facilitated the handling of documents, the shipping, preservation (virtual libraries), processing and distribution of contents; the diffusion of knowledge is practically made as soon as a document processing stage is completed. ${ }^{7}$ Electronic formats have significantly increased publication visibility, by means of which the number of users can considerably grow without budget increases being necessary. In this regard, it is it is necessary to consider that there are publications in electronic open access format and others restricted to paid access.

Gaceta Médica de México has gradually evolved: from the printed version to a dual format, printed and electronic, and from number 2, volume 155, 2019 on, exclusively to electronic, open access and in a bilingual modality, given that all articles are fully published in English and Spanish. ${ }^{8}$

For almost three centuries, medical journals have constituted part of doctors and medicine "collective memory". The increase in the production of medical scientific documents is a phenomenon that is in keeping with technological times. I hope that in the electronic versions they remain as the reservoir of the history of this discipline. Undeniably, the word "hope" implies anticipation, and at the same time doubt.

Where does the doubt come from? I'll explain. In a recent publication on historical aspects related to Gaceta Médica de México, the list of its editors and associate editors from 1864 to 2018 was featured. It drew my attention that, for the 1968-1994 period, only the editors were registered, ${ }^{9}$ which I assumed might be attributed to an editorial policy then established between editors and the boards of directors of the National Academy of Medicine of Mexico. To corroborate this, I undertook the task of reviewing the primary sources, i.e. the Gaceta Médica de México printed numbers of those years in the library of the Academy itself. To my surprise, finding said information was not possible, since the corresponding copies had been bound by volume and the cover page and the legal page with the names of the editors and associate editors had been removed. Then, I turned to the electronic collection of the journal' archives, which was
Table 1. Gaceta Médica de México editors, associate editors and responsible editors during the 1969-1994 period*

\begin{tabular}{|c|c|c|c|}
\hline Year & Editor & $\begin{array}{l}\text { Associate } \\
\text { editor (s) }\end{array}$ & $\begin{array}{l}\text { Responsible } \\
\text { editor }\end{array}$ \\
\hline
\end{tabular}

1968-1969 Silvestre Frenk

1970-1971 Silvestre Frenk Rubén Argüero

Sánchez

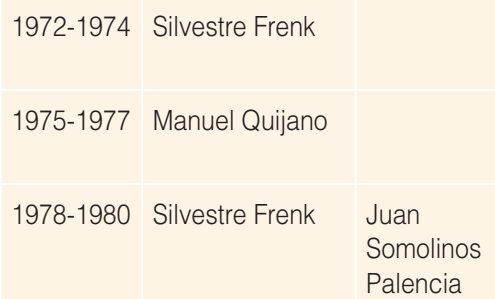

1981-1983 Silvestre Frenk Alejandro

Somolinos

1984-1985 Juan Somolinos Sergio Ponce Alejandro

Palencia de León1 Somolinos

1985-1987 Juan Somolinos Alejandro

Palencia Somolinos

1988-1989 Arturo Zárate Salvador Alejandro

Villalpando2 Somolinos

1990-1992 Juan Somolinos Silvestre

Palencia Frenk3

Daniel

Vasconcelos4

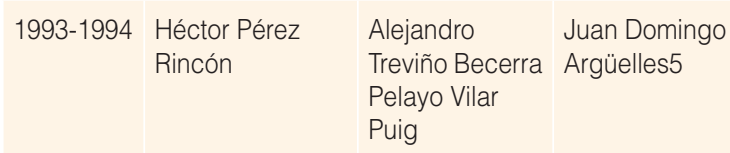

*Source: Legal page of each Gaceta Médica de México issue from Volume 104 (1968) to 130 (1994).

Participated as associate editor until number 3, volume 121 (1985).

2 Joined as associate editor in volume 125 (1989).

${ }^{3}$ Associate editor in volume 126 (1990).

${ }^{4}$ Associate editor in volume 128 (1992).

${ }^{5}$ Was in charge of the care of the edition in 1994. Currently, he serves as editor of the Universidad Iberoamericana journal and as a literary critic and essayist for the Milenio and La Jornada newspapers.

coordinated by Dr. Emilio García Procel. ${ }^{10}$ This collection covers from 1864 to 2007 and compiles all the articles published in those years, sorted by volume and number, but neither does it contain the cover or legal pages. Finally, I decided to go to the National Center of Documented Health Research (CENAIDS - Centro Nacional de Investigación Documental), of the Mexican Institute of Social Security, which has Gaceta complete collections in custody, as the National Autonomous University of Mexico also does. Although Gaceta also had been bound volume-wise, at CENAIDS, the covers and legal pages of each number, where the names of the editors, associate editors and other participants such as coordinators and proof-readers are indicated, had been preserved (Table 1). 
From the above, it seems important to pointing out that journals electronic version omits valuable information that is part of the historical memory of the publications themselves.

Since the second semester of 2017, Gaceta Medica de Mexico has its website (www.gacetamedicademexico. com) on the platform of the publishing house, Permanyer, which responsible for the publishing of the journal, hence the relevance of asking if the information about the editors, associate editors and responsible editors is being preserved. The answer is no, it is not being preserved, which forces us to correct this, we are on time.

Fortunately, Mr. Ricard Permanyer, director General of Permanyer, has shown sensitivity to give continuity to the physical collections of the journal in the libraries of the Academy itself and in that of the National Center of Documented Health Research of the Mexican Institute of Social Security.

\section{Conclusions}

It is the responsibility of the Gaceta Médica of Mexico editors preserving it as part of historical memory of medicine in Mexico, of the social subjects that write and of the topics they write about, regardless of the format. For this, we must make sure that, when the journal is bound, the cover and legal pages are preserved. We should also ensure that on the journal website there is a section with the covers and names of editors, associate editors and responsible editors, and for electronically presented information to be updated for use in the emerging digital systems and to be preserved with professionalism in order to prevent its deterioration.

\section{Epilogue}

Writing did not replace memory; on the contrary, it became a system that enabled storing it. We hope that electronic formats and reservoirs are as efficient as traditional printed documents and libraries have been for preserving historical sources. It is also desirable that the technological changes that occur at an impressive speed do not lead to forget the historical social function of scientific publications. I trust that by 2164, the entire Gaceta Médica de México collection can be electronically searched, when this journal reaches 300 years of existence, just as the printed backup has made it possible for Medical Assays and Observations.

\section{References}

1. Diálogos de Platón. Fedro. Madrid, España: Gredos; 2010. p. 832-834.

2. Viñao-Frago A. Leer y escribir. Historia de dos prácticas culturales. México: Fundación Educación, voces y vuelos, IAP; 1999.

3. Raimondo-Cardona G. Antropología de la escritura. Segunda edición. Barcelona: Gedisa; 1999.

4. Svend D. Historia del libro. México: Consejo Nacional para la Cultura y las Artes/Alianza editorial/Editorial Patria; 1991.

5. De La Torre-Villar E. Elogio y defensa del libro. México: UNAM, Coordinación de Humanidades; 1990.

6. Espinosa-Larrañaga F, Rico-Méndez FG, Becerrill-Ángeles M. Por qué deben escribir los neumólogos. En: Rico-Méndez FG, Romero-López Z, Cisnero-Martínez JA, Ochoa-Vazquez MD. Salud respiratoria. Tópicos selectos. México: Alfil; 2016. p. 907-920

7. Espinosa-Larrañaga F. Publicaciones médicas y tecnologías de la información. Rev Med Mex Seguro Soc. 2013;51(3):244-247.

8. Treviño-Becerra A. Un triángulo de paradojas. Gaceta Médica de México se publicará solo en forma electrónica. Gac Med Mex. 2019;155(39): 219-220.

9. Rodríguez-Pérez ME. Editores de la Gaceta Médica de México, 1864 a 2018. En: Academia Nacional de Medicina. Notas históricas. México: Permanyer-Conacyt; 2018. p. 109-111.

10. Gaceta Médica de México, 1864-2006 [CD producido por Academia Nacional de Medicina y coordinado por Emilio García-Procel]. México: Academia Nacional de Medicina; 2006. 